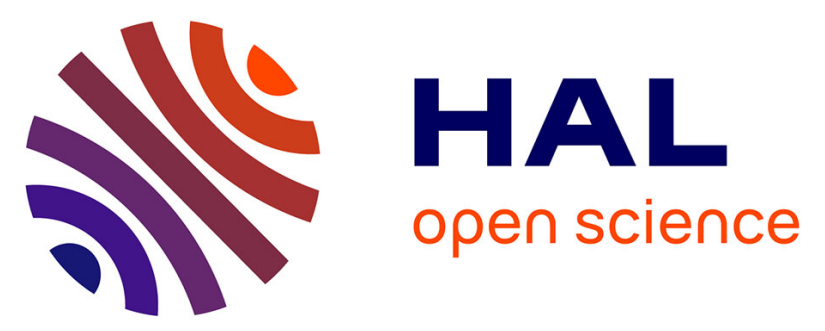

\title{
Behaviour of endangered European eels in proximity to a dam during downstream migration: Novel insights using high accuracy $3 \mathrm{D}$ acoustic telemetry
}

Thomas Trancart, Alexandre Carpentier, Anthony Acou, Valentin Danet, Sophie Elliott, Eric Feunteun

\section{To cite this version:}

Thomas Trancart, Alexandre Carpentier, Anthony Acou, Valentin Danet, Sophie Elliott, et al.. Behaviour of endangered European eels in proximity to a dam during downstream migration: Novel insights using high accuracy 3D acoustic telemetry. Ecology of Freshwater Fish, 2019, 10.1111/eff.12512. hal-02374415

\section{HAL Id: hal-02374415 https://hal.sorbonne-universite.fr/hal-02374415}

Submitted on 21 Nov 2019

HAL is a multi-disciplinary open access archive for the deposit and dissemination of scientific research documents, whether they are published or not. The documents may come from teaching and research institutions in France or abroad, or from public or private research centers.
L'archive ouverte pluridisciplinaire HAL, est destinée au dépôt et à la diffusion de documents scientifiques de niveau recherche, publiés ou non, émanant des établissements d'enseignement et de recherche français ou étrangers, des laboratoires publics ou privés. 


\title{
Behaviour of endangered European eels in proximity to a dam during downstream migration: Novel insights using high accuracy 3D acoustic telemetry
}

\author{
Thomas TRANCART*, Alexandre CARPENTIER, Anthony \\ ACOU, Valentin DANET, Sophie ELLIOTT, Éric FEUNTEUN \\ Museum National d'Histoire Naturelle
}

* Corresponding author: Station marine de Dinard, 38 rue du port blanc, 35800 Dinard, France. E-mail: thomas.trancart@mnhn.fr. Tel: (+33) 2 23185885

Running title: Behaviour of silver European eel at a dam 


\section{Abstract}

1 River infrastructures such as weirs, hydropower stations or water

2 reservoirs represent obstructions to migration for diadromous fish.

3 Knowledge of accurate behaviour of fish in front of such structures is

4 required to protect migrants from hazardous areas, guide them towards

5 safe passage or adapt structure to improve the escapement. We

6 developed and made available a method to process acoustic telemetry

7 data based on Time Difference of Arrival (TDOA) analysis to accurately

8 locate tagged fish. Improved accuracy allows the detection of escape

9 routes and description of dam-crossing tactics. Sixteen tagged eels were

10 tracked with high accuracy $(1-2 \mathrm{~m})$ and $\sim 1$ location $\mathrm{min}^{-1}$ frequency

11 during their exploration period on reaching the dam. Two migration

12 routes (spillways and bottom compensation flow pipe) were used by $77 \%$

13 and $23 \%$ of eels, respectively. Spillways were the preferred route, but a

14 median of 16 days were required to pass the dam versus 1.1 days via the

15 compensation pipe. A minimal water crest of $40 \mathrm{~cm}$ was required for

16 passage via spillways. Eels passing through the compensation pipe were

17 exclusively nocturnal, and mainly explored the bottom of the dam. Eels

18 passing through spillways explored the whole dam area by night and day,

19 and were not attracted to the compensation pipe entrance.

20 With global warming, more frequent drought periods are expected,

21 potentially leading to decreased opportunities for eels to migrate across

22 safer dams by spillways. To conserve this endangered species, dam

23 management strategies that account for expected hydrologic conditions

24 and distinct exploration behaviours are needed.

25 Keywords: European eel, 3D acoustic telemetry, downstream migration, 26 dam, diadromous fish 


\section{Introduction}

29 Diadromous fish are vulnerable because they must migrate between 30 marine and freshwater habitats to reproduce (McDowall, 1988). This

31 breeding migration involves passing through narrow ecological pathways,

32 called corridors, that are being exposed to increased anthropogenic and

33 ecological pressures. The latter has led to major population declines in

34 most diadromous fishes (Limburg \& Waldman, 2009). Recruitment rate 35 of the European eel Anguilla anguilla is currently below 10\%that of the 36 maximum level recorded in the late 1970s (ICES, 2018). Consequently, 37 this species is now far outside its safe biological limits, and is considered 38 as critically endangered by the International Union for Conservation of 39 Nature (IUCN) (Jacoby \& Gollock, 2014). The European Union 40 recommends actions focused on reducing commercial fishing, limiting 41 recreational fishing, adopting restocking measures, increasing watershed 42 connectivity and quality, catching and transporting silver eels, exercising 43 predator control, implementing hydroelectrical turbine shutdowns, and 44 adopting aquaculture measures. These actions were specified to reduce 45 the effects of the most significant causes of decline. Overfishing is 46 considered to be primary cause of decline, followed by mortality induced 47 by turbines and dams (Feunteun, 2002).

48 The impacts of hydropower dams have been well studied. 49 Hydroelectric complexes can cause injuries (Bruijs \& Durif, 2009), direct 50 mortality (Winter, Jansen \& Bruijs, 2006; Bruijs \& Durif, 2009), delays in 51 the timing of migration (Behrmann-Godel \& Eckmann, 2003), and can 52 inhibit downstream migration (Durif, Elie, Gosset, Rives, \& Travade, 53 2003). To date, downstream passage at non-powered dams (i.e. that are 54 not equipped with turbines) have not been considered to be a 55 particularly important issue for migrating silver eels, as the passage is 56 usually considered to be safe (Besson et al., 2016). Consequently, the 57 impact of reservoirs and dams is less studied, despite high numbers 
existing in some European regions. In particular, non-powered dams can delay migration (Besson et al., 2016; Larinier, 2000; Larinier \& Travade, 2002 ) and result in lower (20\%) annual migration rates when compared to equivalent non-obstructed rivers (Feunteun et al., 2000; Acou, 2006). In such systems, the principal route for eels to migrate seaward involves waiting for the overflow during flood episodes. Unfortunately, climate change might have significant consequences on the availability of water resources, with the frequency of overflow periods being expected to decline, particularly in areas already suffering from water stress or that have low groundwater (Versini, Pouget, McEnnis, Custodio, \& Escaler, 2016). To manage this endangered species efficiently, scientists and environmental managers must adapt existing measures to enhance the passage of silver eels through dams under current and future hydrological conditions. As a first step, it is necessary to understand how eels behave in reservoirs and their migration pathways across dams.

3 In recent years, telemetry technology has been used to study the behaviour of a variety of aquatic animals (including fishes, turtles, and mammals) and ecosystems (including oceans, rivers, lakes, and estuaries) (Hussey et al., 2015). To study large-scale migrations (spanning several hundreds or thousands of kilometres), the accuracy needed to locate individuals below a hectometre is generally not an issue (e.g. Renkawitz, Sheehan, \& Goulette, 2012; Rechisky et al., 2013; Beguer-Pon et al., 2014; Righton et al., 2016). However, greater accuracy (approx. $1 \mathrm{~m}$ ) is required to elucidate patterns in fine-scale behaviour (Løkkeborg, Fernö, \& J ørgensen, 2002; Rillahan, Chambers, Howell, \& Watson, 2009), home range movements, and habitat selection (Andrews et al., 2011; Coates, Hovel, Butler, Klimley, \& Morgan, 2013; Espinoza, Farrugia, \& Lowe, 2011), and reproduction (Dulau et al., 2017).

6 Such fine-scale accuracy is required to study the behaviour of eels so that effective management measures can be implemented. Accurate 
88 information on movement is essential to optimize the design and 89 construction of eel passageways and to verify their efficiency (Brown, 90 Haro, \& Boubée, 2007). Currently, two main methods are available and 91 widely used to track species in aquatic systems; namely, satellite and 92 acoustic tracking (Hussey et al., 2015). Although satellite tracking 93 represents the most accurate method of determining location, this 94 technology requires the regular emersion of transmitters so that they can 95 communicate with satellites, making it only suitable for species that 96 remain at, or come regularly to, the water surface (e.g. aquatic 97 mammals, birds, turtles, and some shark species). In comparison, 98 acoustic telemetry has rapidly become the most suitable technology for monitoring fishes (Hussey et al., 2015).

Unfortunately, because sound in water propagates uniformly in all 101 directions, the locations recorded using a single fixed receiver 102 encompass a large area (up to several hundreds of meters) around the 103 receiver. The size of this area depends on factors related to: (1) the 104 characteristics of transmitters (size and type of acoustic transmitter), (2) 105 the environment (e.g. depth, salinity, current, suspended matter, and 106 substrate), and (3) anthropogenic activities that generate noise (e.g. 107 boat traffic and turbines) (Simpfendorfer, Heupel, \& Collins, 2008; 108 Gjelland \& Hedger, 2013; Kessel et al., 2014; Hayden et al., 2016; 109 Huveneers et al., 2016; Reubens et al., 2018). Thus, it is difficult to 110 determine the precise location of an acoustic-tagged animal, although 111 several methods have been designed and developed to improve this 112 accuracy. For example, Simpfendorfer, Heupel, and Hueter (2002) 113 developed a method using presence data from multiple receivers to 114 obtain position estimates (short-term centre of activity) based on the 115 weighted means of the number of signal receptions at each receiver 116 during a specified time period. However, this method can only determine 117 the centre of activity within a given time period, rather than a precise 
118 estimate of location at a single point in time. To obtain precise location

119 estimates at a single time point, numerous companies offer accurate 120 positioning systems with metre or sub-metre resolution using acoustic 121 telemetry. Some of these methods require communication from 122 receivers to reception units with acoustic cables, which is not always 123 feasible.

124 To position tagged aquatic animals accurately without links to 125 receivers, analysis of time difference of arrival (TDOA) has been 126 developed by telemetry manufacturers. Unfortunately, scientific studies 127 using this methodology have not provided sufficient details of the 128 technical methods and calculations to enable reported experiments to 129 be reproduced (see for instance Espinoza et al., 2011; Roy et al., 2014; 130 Guzzo et al., 2018). Moreover, until recently, access to this methodology 131 was via a paid service or software, not via open access services (Baktoft, 132 Gjelland, Økland, \& Thygesen, 2017).

133 Thus, the current study proposed and described the use of a complete 134 methodology to locate tagged silver eels accurately $(\sim 1 \mathrm{~m})$ using TDOA 135 within the Fremur River (north-western France). Using this method, eel 136 behaviour during downstream migration (i.e. exploratory behaviour and 137 avoidance behaviour) was analysed. It is important to understand how 138 silver eels behave and explore their environment in the context of 139 blocked migration. Therefore, the method described here is expected to 140 help advance our understanding of how, how many, where, and when 141 silver eels cross dams. Based on our results, we provide 142 recommendations for conservation managers to facilitate the passage of 143 silver eels blocked upstream of dams by defining optimal escapement 144 routes.

\section{Methods}

\section{$146 \quad 2.1$ Study site}


147 The Bois-J oli dam is located on the Frémur River, north-western France, 148 and was built in 1992. It is a $150 \mathrm{~m}$ long and $15 \mathrm{~m}$ high dam that creates 149 a reservoir of $0.4 \mathrm{~km}^{2}$, with a maximum volume of $3000000 \mathrm{~m}^{3}$. The 150 water level upstream of the dam is monitored and recorded every $10 \mathrm{~min}$. 151 However, this dam is not equipped for downstream eel migration. 152 Downstream migration is possible over the six spillways of the dam (each $1536.8 \mathrm{~m}$ in width) during overflows (Legault et al., 2003; Acou et al., 2008), 154 or through a compensation flow pipe (Figure 1). One of these spillways 155 (spillway 1 ) is located $10 \mathrm{~cm}$ below the other five spillways. The other 156 five spillways are all at the same level (Figure 2). A $40 \mathrm{~cm}$ diameter 157 compensation pipe is present to ensure a minimum instream flow in the 158 Frémur River (Figure 1), which is consistent year-round. The 159 compensation pipe is also used for freshwater intake in a pumping station 160 supplying a water treatment plant. The compensation pipe has five 161 different entrances at five different depths (Figure 2), which are located 162 in a concrete tower at the middle of the dam. Although the pipe has 163 been fitted with a fine metallic grid ( $20 \mathrm{~mm}$ mesh size) to prevent eel 164 passage and mortality, this grid has proved to be inefficient, as numerous 165 eels have been found dead in the filter located beyond the grid.

\section{$166 \quad 2.2$ Silver eel collection and tagging method}

167 Silver eels were captured using fyke nets in the fall of 2017 (October168 december). The fyke nets were positioned in the upstream part of the 169 Bois-J oli Reservoir, and were checked three times a week. Sixteen silver 170 eels were selected using classical external characteristics (Acou et al., 171 2005), anaesthetised with benzocaine (150 $\mathrm{mg} \mathrm{l}^{-1}$ ), and tagged with

172 acoustic transmitters (ID-LP9L-69 kHz Thelma Biotel, Trondheim, Norway, $1739 \mathrm{~mm}$ diameter, $24 \mathrm{~mm}$ long, $4 \mathrm{~g}$ in air, transmission interval 30-90 174 seconds), respecting the $2 \%$ transmitter/ body mass ratio (Winter, 1996). 175 Incisions were closed with absorbable sterile sutures (3-0 ETHICON 
176 MONOCRYLTM, Ethicon Ltd, Livingston, UK) and disinfected with 177 bactericidal antiseptic $(0.05 \%$ chlorhexidine). After a recovery period in 178 a large aerated tank and when all anaesthetic effects had dispersed (full 179 recovery of locomotor movements, usually under $1 \mathrm{~h}$ ), the fish were 180 released $100 \mathrm{~m}$ downstream of the fishing site, which was located about $1813 \mathrm{~km}$ upstream of the dam. Previous survival tests with eels from the 182 same study site that were tagged with the same method showed no death 183 or injury (Trancart et al., 2017); thus, based on the endangered status 184 of European eels and the very low number of silver eels in Fremur River, 185 we chose not to perform survival test for this experiment. The 186 institutional and national guides for the care and use of laboratory 187 animals were followed. Tagging was conducted under the authority of 188 the "certificat capacitaire pour l'expérimentation animale" 189 (experimental animal certificate) no. A29-039-1 of the Museum National 190 d'Histoire Naturelle, Dinard

\section{$191 \quad 2.3$ Acoustic array}

192 Twenty-three acoustic receivers (Thelma Biotel TBR 700) were deployed 193 in three parallel lines along the front of the Bois-J oli Dam (Figure 3). The 194 Thelma Biotel receivers provide time of reception in milliseconds, which 195 is required for the positioning determination method. These receivers 196 were located at $20 \mathrm{~m}$ intervals from each other, covering a $150 \times 50 \mathrm{~m}$ 197 area. The accurate horizontal location (latitude, longitude) of each 198 receiver was determined to the nearest centimetre using a theodolite. 199 The hydrophone depth ( $Z$, vertical position) was measured to the nearest 200 centimetre using a tape measure. To ensure time synchronization 201 between all receivers, a synchronization transmitter (ST) was placed in 202 the reservoir (using the precise theodolite determined latitude, 203 longitude, and depth to the nearest centimetre) (Figure 3). Each receiver 
had an internal temperature sensor that recorded the temperature every 10 min, enabling us to determine the speed of sound in water accurately. To monitor whether the departure of tagged eels from the study area was up- or downstream, additional receivers were placed downstream of the dam and upstream the reservoir (Figure 3).

\subsection{Location estimation in the reservoir}

\section{Horizontal positioning determination method}

The horizontal positioning determination method is based on Time Difference Of Arrival (TDOA). In this method, the location of an acoustic transmitter is calculated from the relative time of acoustic emission received by different hydrophones surrounding the transmitter and according to their relative distance. Time registration by the receivers uses an internal clock based on crystal oscillators. The frequency of these oscillators varies slightly between receivers, inducing temporal drift specific to each receiver. Consequently, the accuracy of an acoustic transmitter location depends both on the accuracy of the time of signal reception by receivers (to the nearest millisecond) and the accuracy of the location of the hydrophones themselves (to the nearest centimetre). This issue required relatively precise synchronization of the different receivers (to the nearest millisecond), and a precise knowledge of their locations (to the nearest centimetre). The method used in the present study involved three steps: (1) database synchronisation and time drift removal, (2) multilateration, and (3) filtering of aberrant results (i.e. positions located out of the study site range), if required. All of the treatments (synchronization, multilateration, and filtering) were performed using R 3.5.0 software (R Development Core Team, 2008). Details on the methods used are provided in Annex 1 to allow the free method to be reproduced by the whole scientific community. 
233 To determine vertical positioning (depth), we used the internal pressure 234 sensor of the Thelma Biotel acoustic depth transmitters (D-LP9). 235 Preliminary tests in an artificial basin $(10 \times 10 \times 10 \mathrm{~m})$ showed the perfect 236 accuracy (to the nearest $10 \mathrm{~cm}$ ) of these sensors, for three test depths $237(2,5$, and $8 \mathrm{~m})$ over a 7 -day period.

\section{Evaluation of the accuracy for horizontal location} determination

240 To validate the method presented here, two stationary reference 241 transmitters were placed at known X-Y-Z positions (to the nearest $\mathrm{cm}$ ) 242 in the reservoir, with a 10 min mean interval between two successive 243 signals throughout the study period. The first test transmitter was 244 located close to the spillways (Figure 3), just in front of the possible 245 routes to exit the reservoir. A second test transmitter was placed close 246 to the shore (Figure 3). The second test transmitter remained in the 247 water throughout the course of the experiment, whereas, due to drought 248 conditions, neighbouring receivers were out of the water during the first 249 part of the experiment in the autumn of 2017. For this test transmitter, 250 the validation period was limited to the period when neighbouring 251 receivers were submerged in the water. The distance between the real 252 position and the calculated positions was calculated to evaluate the 253 accuracy of the method (in metres).

\section{$254 \quad 2.5$ Data analysis}

\section{2.5.1. Estimation of escapement}

256 Individual escapement was estimated using the positioning method 257 previously described and confirmed by the detection of a transmitter by 258 the receiver immediately downstream of the dam. Escapement rate was 
259 defined as the number of silver eels detected below the Bois-J oli Dam

260 against the total number of marked silver eel in the Bois-J oli Reservoir.

262 2.5.2. Estimation of migration routes to pass over

263 the dam

264 Method 1: Observed route using a compensation pipe survey and

265 one acoustic receiver

266 The exit of the compensation pipe was equipped with a net $(6.5 \mathrm{~m}$ long, $2670.5 \mathrm{~m}$ large, $2 \mathrm{~mm}$ mesh size) to control silver eel escapement. Over the 268 study period, the net was inspected approximately once every three days. 269 All captured eels were inspected for the presence of a tag and signs of 270 trauma. All eels that were caught alive were released downstream of the 271 dam. The compensation pipe operates throughout the year and is 272 protected by a grid, but this grid is not fully effective, as silver eels were 273 caught in net.

274 We considered that a silver eel had succeeded in passing the Bois275 J oli dam via the compensation pipe if it was observed in the net. We 276 considered that a silver eel had succeeded in passing this dam via the 277 spillway if it was not observed in the net and it was recorded on the 278 acoustic receiver just downstream of the dam.

280 Method 2: Estimated route using the TDOA method

281 A second method was employed to estimate the most probable escape 282 route from the Bois-J oli Reservoir (i.e. compensation pipe versus 283 spillways). For each eel, the 10 last estimated positions, given by the 284 previous method (see 3.4 Horizontal positioning determination method), 285 were retained to trace the most probable route used. The most probable 
exit route was attributed to a given individual, only if the route and the 287 final estimated location clearly indicated one of the two possible ways 288 of escapement. With this method, the most probable date/ time of the 289 passage can be inferred, and was used to obtain the water level in front 290 of the dam and the height of the water crest (when overflowing) during 291 the passage of the eels.

292

\subsubsection{Exploratory behaviour and efficiency in}

\section{passing}

295 To evaluate the efficiency of eels in passing the dam, four metrics were calculated for each eel:

i. The time to pass (TTP, in days), which was defined as the time

To identify potentially different exploration tactics, another metric was used. For this metric, we only considered presence close to the dam $(<10$ $\mathrm{m})$. The period of presence close to the dam was defined as the period 
315 of the day when an eel was observed close to the dam $(<10 \mathrm{~m})$. This 316 period was analysed. Two periods were defined according the natural 317 luminosity occurring at the study site during the experiment: night 318 (17:00-07:59) and the day (08:00-16:59 PM).

319 Finally, to characterise spatial patterns in exploration, the locations 320 of the individuals were represented from two perspectives: above and 321 frontal. In the view from above, a $30 \times 20$ cells raster (resolution $=0.1$

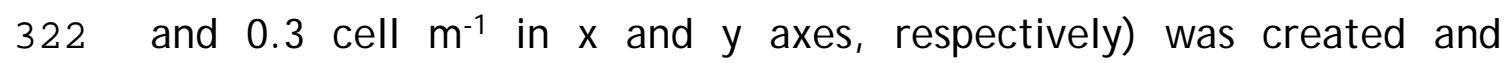
323 superposed to the aerial view of all locations for a given eel. The value 324 of each cell corresponded to the number of detections observed in this 325 cell. In the frontal view facing the dam, a $30 \times 15$ cells raster (resolution $326=0.1$ and 1 cell $\mathrm{m}^{-1}$ in the $\mathrm{x}$ and $\mathrm{y}$ axes, respectively) was used. Eel 327 locations were projected according to an orthogonal projection. The 328 value of each cell corresponded to the number of detections observed in 329 this cell. In both views, percentages were computed afterwards to 330 improve readability.

\section{Results}

\section{$333 \quad 3.1$ Validation of estimated horizontal locations using}

334 test transmitters

335 The median errors of location obtained from the stationary reference 336 transmitters located at fixed positions were 1.14 and $1.64 \mathrm{~m}$, and ranged 337 from 0.07 to $36.76 \mathrm{~m}(\mathrm{n}=3413$ locations over $169 \mathrm{~d}$ ) (Table 1$)$. The 338 cumulative frequencies in the distribution of the error locations of the 339 two reference transmitters indicated that the positioning error was less 340 than $2 \mathrm{~m}$ for $80 \%$ and $70 \%$ of locations for stationary reference

341 transmitter 1 and 2, respectively, and less than $5 \mathrm{~m}$ for $100 \%$ and $93 \%$ of 
342 locations for transmitters 1 and 2, respectively (Figure 4). For both 343 transmitters, inframetric accuracy was reached for $30 \%$ of locations.

\subsection{Estimation of the most probable routes of exit}

345 Based on the first method, 13 silver eels were observed downstream the 346 Bois-J oli Dam, and only three were captured in the net, suggesting that 347 the other ten passed over the dam via the spillways.

348 Based on the second method, the principal migration route was 349 the spillways, because 10 eels used it. Nine eels crossed the dam by the 350 first spillway (Figure 5). The other three eels used the compensation pipe 351 (Figure 6). The migration pathways used by tagged silver eels determined 352 from the two methods (surveys and TDOA alone) were identical (Table 353 2). This method allowed us to elucidate the probable time and date of 354 the passage, and the water level in front of the dam. The water crest 355 height above spillway \#1 ranged from $40 \mathrm{~cm}$ to $53 \mathrm{~cm}$ (table 2) during eel 356 passage. These heights were rapidly reached after the onset of the overflow (48 hours at $40 \mathrm{~cm}$ level).

\subsection{Efficiency in crossing the dam}

360 The Time To Pass (TTP) the Bois-J oli Dam ranged from 0.29 to $65 \mathrm{~d}$ (Table 3613 and Fig. 7). The median time for eels to pass through the compensation 362 pipe was shorter ( $1.1 \mathrm{~d}$ ) than those passed through the spillways (18.53 $363 \mathrm{~d}$ ). When considering the date and time when the dam began to overflow 364 (15 December, at 15:00), the time to pass (TTP-0) the spillways was 36516.53 days (Table 3 and Fig. 7). Eels that passed through the 366 compensation pipe had the highest number of detections close to the 367 dam per day (TND/ d). Yet, the Total Number of Detections (TND) close 368 to the dam was similar for both groups (Table 3 and Fig. 7).

\section{$369 \quad 3.4$ Behaviours during escape attempts}


372 A very strong behavioural difference was observed between silver eels 373 that used spillways versus the compensation pipe. In the final period of 374 movement (just before passing), those passing through the spillways had 375 a higher swimming speed, beginning their final displacement further 376 from the dam (Figure 5). In comparison, those passing through the 377 compensation pipe had lower swimming speeds and visited the entrance 378 for a long duration (Figure 6). Although the number of eels that passed 379 through the compensation pipe was too low (three) to allow for 380 statistical comparison, their body weights were equivalent to those of 381 eels that passed through the spillways $(554.1 \pm 193.56 \mathrm{~g}$ and $515 \pm 225.3$ $382 \mathrm{~g}$ for spillways and compensation pipe, respectively).

383 Eels that passed through the compensation pipe only explored the 384 waterways at night. In comparison, eels that used the spillways explored 385 the dam during day for $10-40 \%$ of records. A strong difference was also 386 documented for the locations of detections close to the dam $(<10 \mathrm{~m})$ 387 between eels that passed through the compensation pipe and eels that 388 passed through spillways. The first ones were mainly located close to the 389 compensation pipe. The right side of the dam was also explored, while 390 the left side was explored less (Figure 8).

391 In contrast, the areas close to the compensation pipe were not 392 explored more than other areas by eels that passed through the spillways. 393 Most detections were recorded the right side, close to the bottom. No 394 clear difference was observed between the periods before (Figure 9, 395 upper slide) and during overflow (Figure 9 lower slide). During overflow, 396 the range of explored areas seemed to be higher than before overflow. 397 However, this phenomenon was just an artefact linked to the number of 398 detections during both periods (1880 and 3347 detections for periods 399 before and during overflowing, respectively). 


\section{Discussion}

402 This study demonstrate the behaviour of endangered silver European eel 403 attempting to cross a dam using high accuracy 3D acoustic telemetry 404 based on Time Difference Of Arrival analysis. This method is described 405 in the annex so it may be reproduced without the need for payment of 406 software and services. The method developed here produced sufficiently 407 accurate location $(<2 \mathrm{~m})$, allowing the precise description of eel 408 behaviour. Eels used two escape routes, with some behavioural 409 differences being detected between these two groups.

\section{4.1 Accuracy of the location determination method}

412 The method presented in the current study showed a median location 413 error of approximately $1.14 \mathrm{~m}$ for test transmitter \#1 and approximately $4141.64 \mathrm{~m}$ for test transmitter \#2. The first test transmitter was located 415 very close to the potential exit routes for eels. For this test transmitter, 416 the location accuracy was constant throughout the study period 417 (12/09/17-28/02/18). The second test transmitter was placed close $(<10$ $418 \mathrm{~m})$ to the shore. At the beginning of the experiment, the receivers close 419 to this transmitter were out of the water and, therefore, not operational 420 until the water level had risen and submerged the receivers. Given that 421 Espinoza et al. (2011) showed the error was significantly lower inside 422 than outside an array, errors were only calculated for the period (after 423 15th December), when all the receivers were submerged.

424 The accuracy in the present study was better than, or equivalent 425 to, that reported in comparable studies using commercial positioning 426 systems. For example, Espinoza et al. (2011) showed that the mean 427 positional accuracy of Vemco Positioning System (VPS) estimates from a 
stationary transmitter deployed at several locations within the receiver array was $2.64 \pm 2.32 \mathrm{~m}$. In comparison, Guzzo et al. (2018) found that the accuracy estimates of HR-VPS positions for all stationary trials was $5.6 \mathrm{~m}$. Biesinger et al. (2013) demonstrated a positional accuracy of approximately $2 \mathrm{~m}$. This improved accuracy could be explained by: (i) the positioning of the receiver to the nearest centimetre using a theodolite for $\mathrm{x}$ and $\mathrm{y}$ coordinates, and using a decametre for $\mathrm{z}$, and (ii) the real-time measurement of water temperature to continuously correct the speed of sound in water at the exact moment of acoustic signal reception. This was possible using the intern thermic sensor included in Thelma Biotel receivers.

A novel positioning method has recently been presented, involving Maximum Likelihood analysis of a state-space model applied directly to time of arrival (Baktoft et al., 2017). This method is free, unlike vendorsupplied solutions, and it is transparent and accurate. However, the accuracy of the location determination method presented and used in the present study was sufficiently good for the fine-scale analysis of movements, as required in the present context of silver eel downstream migration.

\subsection{A paradox in the choice of escape routes}

The two methods used produced the same results (three eels by compensation pipe, 10 eels by spillways). However, the second method using TDOA provided a greater level of accuracy. The second method showed that, for nine eels, the most probable route out of the six spillways was the first one (with a lower overflow crest). For one eel, the last detection was too far from the spillway to determine the spillway used.

Seventy seven percent of individuals used spillways to successfully cross the Bois-J oli dam. When both routes were available at the same 
458 time (i.e. during the overflow period), no eel passed through the 459 compensation pipe. Although spillways were the principal route used, it 460 is still not clear if it is a beneficial one. For instance, the downstream 461 movement of eels predominantly occurs close to the river bed (Brown \& 462 Castro-Santos, 2009; Gosset, Travade, Durif, Rives, \& Elie, 2005), 463 therefore eels may prefer bottom fishways over surface ones. However, 464 the compensation pipe might induce strong rejection, resulting in most 465 eels using a surface route (spillway). The limited diameter of the intake 466 pipe is highly restrictive, accelerating flow (Legault, Acou, Guillouët, \& 467 Feunteun, 2003), which might also deter eels. Finally Piper et al. (2015) 468 observed that eels tend to move rapidly back upstream when exposed to 469 high velocity gradients downstream. Although the grid covering the 470 compensation pipe was not fully effective at preventing eels from 471 entering, visual inspection is required to evaluate its impact on eel 472 migration.

473 From when the overflow started operating, the delay in eels using 474 the spillway was quite long, ranging from 3 to 22 days. In comparison, 475 the delay in using the compensation pipe was shorter (maximum 2 days), 476 but was less used. Thus, a paradox was generated between a "slow" 477 principal route and a "fast" incidental one. Spillways also probably 478 induced a form of repulsion, which could be linked to several factors, 479 including the water current speed and their positioning (surface). The 480 depth of water passing over the crest could be another factor slowing 481 their use, because all tagged eels only used the spillways when the water 482 crest height exceeded $40 \mathrm{~cm}$, which was a minimum of $48 \mathrm{~h}$ after the 483 onset of the overflow period.

$484 \quad$ Eels that passed through the compensation pipe exhibited a long 485 final period of exploration (time spent within $10 \mathrm{~m}$ of the dam), slow 486 movements before passing, nocturnal activity, and narrow exploration 487 areas located close to the compensation pipe, at around 6-7 m depth 
488 (i.e. depth of the pipe mouth). In comparison, eels that passed through 489 the spillways showed a short final period of exploration, fast movement 490 before passing, were active both day and night, and explored large areas. $491 \quad$ Even if the total time to pass (time difference between the first 492 detection at the front of the dam and effective passage) was shorter for 493 eels that passed through the compensation pipe, their final time of 494 exploration was similar to that of eels that passed via spillways. Eels 495 passing through the compensation pipe were faster, but not more 496 efficient, since they exhibited more exploratory behaviour. Finally, 497 differences in depth use by eels was detected. Eels that passed through 498 the spillways preferentially explored surface areas. This phenomenon 499 might be linked to individual differences in the perception of the 500 environment and migration cues.

501

\section{$502 \quad 4.3$ Behaviour during escape attempts}

503 Very few studies have analysed the behaviour of eels in front of dams. 504 Comparative studies have mostly been conducted at hydroelectric 505 project intakes, not reservoirs, as in the present study. For instance, 506 Brown, Haro, and Boubée (2007) conducted a 3D-telemetry experiment 507 to track 21 silver eels that encountered a hydroelectric power station 508 during the downstream migration. Brown et al. (2007) showed that 509 longfin eels (A. dieffenbachia) and shortfin eels (A. australis) primarily 510 migrated at night, and that most eels entered the reservoir in the mid511 channel section. Residence time in the reservoir ranged from several 512 minutes to 10 hours. Several eels swam back upstream before returning 513 and continuing to search for a route through. The only downstream 514 passage outlets in the reservoir were the turbine intakes. Two types of 515 behavioural responses were observed when eels encountered the power 516 station intake trash racks, with these responses being species-specific. 
517 Eels either passed directly through the trash racks or intakes on their

518 first encounter, or they immediately rejected entrainment and began

519 searching for an alternative passage route in the forebay or upstream of

520 the detection zone. Shortfin eels were the only species that exhibited

521 this behaviour. Longfin eels made a significantly greater number of

522 attempts to pass downstream via the turbines, which corresponded with

523 significantly longer residence times in the reservoir than shortfin eels,

524 possibly searching for alternate passage locations.

525 Twenty American silver eels (A. rostrata) were tracked using the

526 same technology ( $\mathrm{HTI} \odot$ ) in the Connecticut River (Massachusetts, USA)

527 (Brown \& Castro-Santos, 2009). Tracked eels were detected at all depths,

528 but mostly occurred near the bottom, with occasional vertical

529 movements. This behaviour was interpreted as downstream searching

530 behaviour. A large number of eels was detected re-entering the acoustic

531 array on multiple dates before passing the dam, with many passing

532 through the dam via the turbines.

533 In another study, nine European eels were tagged using acoustic

534 transmitters (Sonotronics ()) in the Mosel River (Germany) (Behrmann-

535 Godel \& Eckmann, 2003). When migrating eels arrived at the dam, they

536 either immediately passed through the turbines or remained upstream

537 of the powerhouse for up to $8 \mathrm{~d}$. During this period, they exhibited a

538 repeated behaviour: approaching the trash rack, sprinting upstream, and

539 finally passing through the turbines. This phenomenon was also clearly

540 present in our study. The lag between two successive transmissions was

541 approximately 60 seconds, suggesting that the number of detections

542 close to the dam could be used as a proxy of the time spent in the area

543 closest to the dam $(<10 \mathrm{~m})$. The strong difference between the time

544 spent close to the dam and the total time to pass suggests repeated entry

545 to the area in close proximity to the dam. Moreover, the detailed analysis

546 of eel traj ectories before passing indicated repeated movement from the 
547 mouth to the reservoir, and following the right-hand shore of the basin, 548 until they finally escaped via the spillways.

549 The movement patterns detected close to hydroelectric intakes 550 from the aforementioned studies were similar to those documented by 551 the present study, including repeated behaviour, bottom prospecting, 552 occasional vertical movement, nocturnal activity, and repulsion. Thus, 553 equipped and non-equipped dams should be managed in the same way.

\section{4.4 Proposed management under global change}

556 The present study showed that the two available routes for the 557 downstream migration of silver eel are not fully suited for this purpose, 558 leading to delays in migration and repulsion from the openings. Moreover, 559 global change and expected recurrent drought periods might compromise 560 the possibility for eels to use spillways to cross dams. For instance, the 561 overflow period has been increasingly delayed each year (over the last 56225 years of observations), with no overflow period occurring in 2018-2019. 563 If eels are not able to use spillways, the only route available is the 564 compensation pipe. This route is, however, dangerous with high rates of 565 trauma and mortality (Legault et al., 2003). Suggested solutions to 566 improve the management of eels include: (i) removing the repulsion 567 effect of both the compensation pipe and spillways, e.g. reducing the 568 water velocity and increasing the depth of spillways, and (ii) adapting 569 the spillways to severe drought periods expected in the future (e.g. with 570 mobile spillway crests). Further studies are required to design viable

571 escape routes that encompass the different behaviours observed in this 572 study and previous studies.

573

\section{Acknowledgements}


575 This study was funded by the 'Agence de l'Eau Loire Bretagne', the

576 'Region Bretagne' and the 'Syndicat Eau du pays de Saint-Malo'. The

577 study was conducted by the Museum National d'Histoire Naturelle. We

578 warmly thank Fish Pass (Virgile, Fabien, Yohan, Francois and Mathieu)

579 and Museum National d'Histoire Naturelle (J ezabel Lamoureux) teams

580 and all the people that helped with sampling and data gathering.

581

582

583

584

585

586

587

588

589

590

591

592

593

594

595

596

597

598

599

600

601

602

603

604

605

606

607

\section{Data Availability Statement}

The data that support the findings of this study are available from the corresponding author upon reasonable request.

\section{Bibliography}

Acou, A, Boury, P., Laffaille, P., Crivelli, A. J., \& Feunteun, E. (2005). Towards a standardized characterization of the potentially migrating silver European eel (Anguilla anguilla, L.). Archiv Für Hydrobiology, 164, 237-255.

Acou, Anthony. (2006). Bases biologiques d'un modèle pour estimer la biomasse féconde de l'anguille européenne en fonction des recrues fluviales et du contexte de croissance: approche comparative à l'échelle de petits bassins versants. Rennes 1 . Andersen, A. C. (2011). Comparative Analysis of Multilateration Methods for Signal Emitter Positioning. Retrieved from http://blog . andersen . im/2012/07/signal-emitter positioning-using-multilateration/

Andrews, K. S., Tolimieri, N., Williams, G. D., Samhouri, J. F., Harvey, C. J., \& Levin, P. S. (2011). Comparison of fine-scale acoustic monitoring systems using home range size of a demersal fish. Marine Biology, 158(10), 2377. https://doi.org/10.1007/s00227-011-1724-5 
608

609

610

611

612

613

614

615

616

617

618

619

620

621

622

623

624

625

626

627

628

629

630

631

632

633

634

635

636

637

638

639

640

641

642

643

644

645

646

647

648

649

650

651

652

Baktoft, H., Gjelland, K. Ø., Økland, F., \& Thygesen, U. H. (2017). Positioning of aquatic animals based on time-of-arrival and random walk models using YAPS (Yet Another Positioning Solver). Scientific Reports, 7(1), 14294.

https://doi.org/10.1038/s41598-017-14278-z

Beguer-Pon, M. , Castonguay, M., Benchetrit, J., Hatin, D., Verreault, G., Mailhot, Y., ... Dodson, J. J. (2014). Large-scale migration patterns of silver American eels from the St. Lawrence River to the Gulf of St. Lawrence using acoustic telemetry. Canadian Journal of Fisheries and Aquatic Sciences, 71(10), 1579-1592. https://doi.org/10.1139/cjfas-2013-0217

Behrmann-Godel, J., \& Eckmann, R. (2003). A preliminary telemetry study of the migration of silver European eel (Anguilla anguilla L.) in the River Mosel, Germany. Ecology of Freshwater Fish, 12, 196-202.

Besson, M., Trancart, T., Acou, A., Charrier, F., Mazel, V., Legault, A., \& Feunteun, E. (2016). Disrupted downstream migration behaviour of European silver eels (Anguilla anguilla, L.) in an obstructed river. Environmental Biology of Fishes, 99(10), 779-791. https://doi.org/10.1007/s10641$016-0522-9$

Biesinger, Z., Bolker, B. M., Marcinek, D., Grothues, T. M., Dobarro, J. A., \& Lindberg, W. J. (2013). Testing an autonomous acoustic telemetry positioning system for fine-scale space use in marine animals. Journal of Experimental Marine Biology and Ecology, 448, 46-56. https://doi .org/10.1016/J . JEMBE . 2013.06. 007

Brown, L., \& Castro-Santos, T. (2009). Threedimensional movement of silver-phase American eels in the forebay of a small hydroelectric facility. American Fisheries Society Symposium, 58(March 2016), 277-291.

Brown, L., Haro, A., \& Boubée, J. (2007). Behaviour and fate of downstream migrating eels at hydroelectric power station intakes. 'roceedings of the 6th International Symposium on Ecohydraulics, 18-23 February, "Bridging the Gap Between Hydraulics and Biology". Christchurch New Zealand. 
653

654

655

656

657

658

659

660

661

662

663

664

665

666

667

668

669

670

671

672

673

674

675

676

677

678

679

680

681

682

683

684

685

686

687

688

689

690

691

692

693

694

695

696

Bruijs, M. C. M., \& Durif, C. M. F. (2009). Silver eel migration and behaviour. In Spawning Migration of the European Eel: Reproduction index, a useful tool for conservation management ( $\mathrm{pp}$. 75-95). https://doi.org/10.1007/978-1-4020-9095-0_4

Coates, J., Hovel, K., Butler, J., Klimley, A., \& Morgan, G. (2013). Movement and home range of pink abalone Haliotis corrugata: implications for restoration and population recovery. Marine Ecology Progress Series, 486, 189-201. Retrieved from https://www.int res.com/abstracts/meps/v486/p189-201/

Dulau, V., Pinet, P., Geyer, Y., Fayan, J., Mongin, P., cottarel, G., ... Cerchio, S. (2017). Continuous movement behavior of humpback whales during the breeding season in the southwest Indian Ocean: on the road again! Movement Ecology, 5, 11. https://doi.org/10.1186/s40462-017-0101-5

Durif, C., Elie, P., Gosset, C., Rives, J., \& Travade, F. (2003). Behavioral study of downstream migrating eels by radio-telemetry at a small hydroelectric power plant. In D. DA (Ed.), Biology, Management, and Protection of Catadromous Eels (Vol. 33, pp. 343-356). Bethesda, Maryland: American Fisheries Society Symposium.

Espinoza, M., Farrugia, T. J., \& Lowe, C. G. (2011). Habitat use, movements and site fidelity of the gray smooth-hound shark (Mustelus californicus Gill 1863) in a newly restored southern California estuary. Journal of Experimental Marine Biology and Ecology, 401(1-2), 63-74. https://doi.org/10.1016/J. JEMBE. 2011.03.001

Espinoza, M., Farrugia, T. J., Webber, D. M., Smith, F., \& Lowe, C. G. (2011). Testing a new acoustic telemetry technique to quantify long-term, finescale movements of aquatic animals. Fisheries Research, 108(2-3). Retrieved from http://wWw. sciencedirect.com/science/article/B6T6N $-520 \mathrm{~J} 94 \mathrm{Y}-3 / 2 / 89 \mathrm{c} 32885 \mathrm{c} 3 \mathrm{e} 670 \mathrm{Ob} 721 \mathrm{c} 810 \mathrm{ef} 80 \mathrm{f} 9632 \mathrm{e}$

Feunteun, E. (2002). Management and restoration of European eel population (Anguilla anguilla): An impossible bargain. Ecological Engineering, 18(5), 575-591. https://doi.org/10.1016/S09258574( 02 2) $00021-6$ 
Feunteun, E., Acou, A., Laffaille, P., \& Legault, A. (2000). European eel (Anguilla anguilla): prediction of spawner escapement from continental population parameters. Canadian Journal of Fisheries and Aquatic Sciences, 57(8), 1627-1635. https: //doi.org/10.1139/cjfas-57-8-1627

Gjelland, K. 0., \& Hedger, R. D. (2013). Environmental influence on transmitter detection probability in biotelemetry: developing a general model of acoustic transmission. METHODS IN ECOLOGY AND EVOLUTION, 4(7), 665-674. https://doi.org/10.1111/2041-210X.12057

Gosset, C., Travade, F., Durif, C., Rives, J., \& Elie, P. (2005). Test of two types of bypass for downstream migration of eels at a small hydroelectric power plant. River Research and Applications, 21, 1095-1105.

Guzzo, M. M., Van Leeuwen Travis, E., Hollins, J., Koeck, B., Newton, M. , Webber Dale, M. , ... Killen, S. S. (2018). Field testing a novel high residence positioning system for monitoring the fine-scale movements of aquatic organisms. Methods in Ecology and Evolution, $\odot(\odot)$. https://doi.org/10.1111/2041$210 \times .12993$

Hayden, T. A., Holbrook, C. M., Binder, T. R., Dettmers, J. M., Cooke, S. J., Vandergoot, C. S., \& Krueger, C. C. (2016). Probability of acoustic transmitter detections by receiver lines in Lake Huron: results of multi-year field tests and simulations. Animal Biotelemetry, 4(1), 19. https://doi.org/10.1186/s40317-016-0112-9

Hussey, N. E., Kessel, S. T., Aarestrup, K., Cooke, S. J., Cowley, P. D., Fisk, A. T., ... Whoriskey, F. G. (2015). Aquatic animal telemetry: A panoramic window into the underwater world. Science (New York, N.Y.), 348(6240), 1255642. https://doi.org/10.1126/science.1255642

Huveneers, C., Simpfendorfer, C. A., Kim, S., Semmens, J. M., Hobday, A. J., Pederson, H., ... Harcourt, R. G. (2016). The influence of environmental parameters on the performance and detection range of acoustic receivers. Methods in Ecology and Evolution, 7(7), 825-835. https://doi.org/10.1111/2041-210X.12520

ICES. (2018). Report of the Joint EIFAAC/ICES/GFCM Working Group on Eels (WGEEL). Kavala, Greece. 
743

744

745

746

747

748

749

750

751

752

753

754

755

756

757

758

759

760

761

762

763

764

765

766

767

768

769

770

771

772

773

774

775

776

777

778

779

780

781

782

783

784

785

786

787

Jacoby, D., \& Gollock, M. (2014). Anguilla anguilla. https://doi.org/http://dx. doi.org/10.2305/IUCN. UK. 2014-1. RLTS. T60344A45833138. en

Kessel, S. T., Cooke, S. J., Heupel, M. R., Hussey, N. E., Simpfendorfer, C. A., Vagle, S., \& Fisk, A. T. (2014). A review of detection range testing in aquatic passive acoustic telemetry studies. Reviews in Fish Biology and Fisheries, 24(1), 199218. https://doi.org/10.1007/s11160-013-9328-4 Larinier, M. (2000). Dams in Fish Migration. In G. Berkamp McCartney, M., Dugan, P., McNeely, J., Acreman, M. (Ed.), Dams, ecosystem functions and environmental restoration: Vol. Thematic $R$ (pp. 123). Cape Town.

Larinier, M., \& Travade, F. (2002). Downstream migration: Problems and facilities. Bulletin Français de La Pêche et de La Pisciculture, (364), 181-207.

Legault, A., Acou, A., Guillouët, J., \& Feunteun, E. (2003). Suivi de la migration d'avalaison des anguilles par une conduite de débit réservé. Bull. Fr. Pêche Piscic., (368), 43-54. https : //doi.org/10.1051/kmae : 2003035

Limburg, K. E., \& Waldman, J. R. (2009). Dramatic Declines in North Atlantic Diadromous Fishes. Bioscience, 59(11), 955-965. https://doi.org/10.1525/bio.2009.59.11.7

Løkkeborg, S., Fernö, A., \& Jørgensen, T. (2002). Effect of position-fixing interval on estimated swimming speed and movement pattern of fish tracked with a stationary positioning system. Hydrobiologia, 483(1), 259-264.

https://doi.org/10.1023/A:1021312503220

McDowall, R. M. (1988). Diadromy in fishes: migration between freshwater and marine environments. London LB - Doc: Croom Helm.

Piper, A. T., Costantino, M., Fabio, S., Andrea, M., Wright, R. M., \& Kemp, P. S. (2015). Response of seaward-migrating European eel (Anguilla anguilla) to manipulated flow fields. Proceedings of the Royal Society B: Biological Sciences, 282(1811), 20151098. https://doi.org/10.1098/rspb.2015.1098

R Development Core Team. (2008). R: A Language and Environment for Statistical Computing. Retrieved from http://wWw.r-project.org 
Rechisky, E. L., welch, D. W., Porter, A. D., JacobsScott, M. C., \& Winchell, P. M. (2013). Influence of multiple dam passage on survival of juvenile Chinook salmon in the Columbia River estuary and coastal ocean. PROCEEDINGS OF THE NATIONAL ACADEMY OF SCIENCES OF THE UNITED STATES OF AMERICA, $110(17), 6883-6888$. https ://doi.org/10.1073/pnas . 1219910110

Renkawitz, M. D., Sheehan, T. F., \& Goulette, G. S. (2012). Swimming Depth, Behavior, and Survival of Atlantic Salmon Postsmolts in Penobscot Bay, Maine. TRANSACTIONS OF THE AMERICAN FISHERIES SOCIETY, 141(5), 1219-1229.

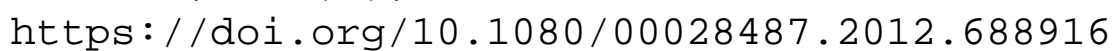

Reubens, J., Verhelst, P., van der Knaap, I., Deneudt, K., Moens, T., \& Hernandez, F. (2018).

Environmental factors influence the detection probability in acoustic telemetry in a marine environment: results from a new setup. Hydrobiologia. https://doi org/10.1007/s10750-0173478-7

Righton, D., Westerberg, H., Feunteun, E., Økland, F., Gargan, P., Amilhat, E., ... Aarestrup, K. (2016). Empirical observations of the spawning migration of European eels: The long and dangerous road to the Sargasso Sea. Science Advances, 2(10). https://doi.org/10.1126/sciadv. 1501694

Rillahan, C., Chambers, M., Howell, W. H., \& Watson, W. H. (2009). A self-contained system for observing and quantifying the behavior of Atlantic cod, Gadus morhua, in an offshore aquaculture cage. Aquaculture, 293(1-2), 49-56. https://doi.org/10.1016/J . AQUACULTURE . 2009.04.003 Roy, R., Beguin, J., Argillier, C., Tissot, L., Smith, F., Smedbol, S., \& De-Oliveira, E. (2014). Testing the VEMCO Positioning System: spatial distribution of the probability of location and the positioning error in a reservoir. Animal Biotelemetry, 2(1), 1. https://doi.org/10.1186/2050-3385-2-1 
Simpfendorfer, C A, Heupel, M. R., \& Collins, A. B. (2008). Variation in the performance of acoustic receivers and its implication for positioning algorithms in a riverine setting. Canadian Journal of Fisheries and Aquatic Sciences, 65(3), 482-492. Retrieved from http : //WwW. scopus . com/inward/record . url?eid=2 s2.0$40849097542 \&$ par tner ID $=40 \& \mathrm{md} 5=\mathrm{a} 696 \mathrm{e}$ f $6 \mathrm{bf} \odot 487 \mathrm{f} 9371067$ ddaOb419a16

Simpfendorfer, Colin A, Heupel, M. R., \& Hueter, R. E. (2002). Estimation of short-term centers of activity from an array of omnidirectional hydrophones and its use in studying animal movements. Canadian Journal of Fisheries and Aquatic Sciences, 59(1), 23-32. https://doi.org/10.1139/f01-191

Trancart, T., Feunteun, E., Danet, V., Carpentier, A., Mazel, V., Charrier, F., ... Acou, A. (2017). Migration behaviour and escapement of European silver eels from a large lake and wetland system subject to water level management (Grand-Lieu Lake, France): New insights from regulated acoustic telemetry data. Ecology of Freshwater Fish, 1-10. https://doi.org/10.1111/eff.12371 Versini, P.-A., Pouget, L., McEnnis, S., Custodio, E., \& Escaler, I. (2016). Climate change impact on water resources availability: case study of the Llobregat River basin (Spain). Hydrological Sciences Journal, 61(14), 2496-2508. https://doi.org/10.1080/02626667.2016.1154556

Winter, J. D. (1996). Advances in underwater biotelemetry (B. R. Murphy \& D. W. Willis, Eds.). Bethesda: American Fisheries Society.

Winter, H. V, Jansen, H. M., \& Bruijs, M. C. M. (2006). Assessing the impact of hydropower and fisheries on downstream migrating silver eel, Anguilla anguilla, by telemetry in the River Meuse. Ecology of Freshwater Fish, 15(2), 221-228. Retrieved from http : //WwW . scopus . com/inward/record . url?eid=2s2.033744818498\&partner ID $=40 \&$ md5 $=6011$ eaaec $895 \mathrm{fb} 4796 \mathrm{dfc}$ 5 b883067a58 


\section{Authors' Contribution Statement}

$874 \mathrm{TT}, \mathrm{AA}, \mathrm{AC}$ and EF conceived and designed the investigation. VD and TT

875 performed the field work. TT wrote the R script and analysed the data.

876 AA, EF and AC interpreted the data. All authors discussed the results and

877 contributed to the final manuscript.

878

\section{Tables}

880 Table 1. Validation results of the estimated horizontal locations for test transmitter \#1 (close 881 to the possible exit routes) and test transmitter \#2 (close to the shore)

\begin{tabular}{|l|c|c|}
\hline & Test transmitter \#1 & Test transmitter \#2 \\
\hline Number of estimated locations & 2355 & 1058 \\
\hline Period & $\begin{array}{r}\text { 12 September to 28 } \\
\text { February }\end{array}$ & $\begin{array}{c}12 \text { December to } 28 \\
\text { February }\end{array}$ \\
\hline $\begin{array}{l}\text { Number of aberrations } \\
\text { (out the receiver array) }\end{array}$ & $3(0.12 \%)$ & $1(0.09 \%)$ \\
\hline Median error (m) & 1.14 & 1.64 \\
\hline Minimum error (m) & 0.33 & 0.07 \\
\hline Maximum error (m) & 18.38 & 36.76 \\
\hline $75 \% 90 \%$ and 95\% quantile (m) & $2.00,2.78,3.32$ & $2.42,4.54,6.41$ \\
\hline
\end{tabular}

882

Table 2. Determination of the migration route selected by silver eels (Anguilla anguilla) according to the observed migration route (first method) and estimated migration route using TDOA (second method), and estimation of the height of the water crest during passage using the second method.

\begin{tabular}{|l|l|l|}
\hline Eel number & $\begin{array}{c}\text { Observed migration route } \\
\text { (first method) }\end{array}$ & $\begin{array}{c}\text { Estimated migration route using } \\
\text { TDOA (second method) }+ \\
\text { estimation of the height of the } \\
\text { water crest during passage }\end{array}$ \\
\hline$\# 17$ & Spillway & Spillway $/ 47 \mathrm{~cm}$ \\
\hline$\# 18$ & Spillway & Spillway \#1 $/ 44 \mathrm{~cm}$ \\
\hline$\# 21$ & Spillway & Spillway \#1 $/ 52 \mathrm{~cm}$ \\
\hline$\# 22$ & Compensation pipe & Compensation pipe \\
\hline
\end{tabular}




\begin{tabular}{|l|l|l|}
\hline$\# 23$ & Compensation pipe & Compensation pipe \\
\hline$\# 24$ & Spillway & Spillway \#1 / 46 cm \\
\hline$\# 25$ & Spillway & Spillway \#1 / 43 cm \\
\hline$\# 26$ & Spillway & Spillway \#1 / $50 \mathrm{~cm}$ \\
\hline$\# 27$ & Compensation pipe & Compensation pipe \\
\hline$\# 28$ & Spillway & Spillway \#1 / 40 cm \\
\hline$\# 29$ & Spillway & Spillway \#1 / 43cm \\
\hline$\# 30$ & Spillway & Spillway \#1 / 46 cm \\
\hline$\# 31$ & Spillway & Spillway \#1 / 41 cm \\
\hline
\end{tabular}

887

888

889

890

891

892

893

894

895

896

897

898

899

900

Table 3. Statistics of migration efficiency for the 13 silver migrating eels that passed the Bois-J oli Dam via spillways (SW) or the compensation pipe (CP). The negative number in the second column indicates passage before the overflow was operational.

\begin{tabular}{|c|c|c|c|c|}
\hline & $\begin{array}{c}\text { Median } \\
\text { number of } \\
\text { days to pass } \\
\text { through the } \\
\text { dam (all } \\
\text { period) }\end{array}$ & $\begin{array}{c}\text { Median } \\
\text { number of } \\
\text { days to pass } \\
\text { through the } \\
\text { dam (after } \\
\text { overflow) }\end{array}$ & $\begin{array}{c}\text { Median } \\
\text { number of } \\
\text { detections } \\
\text { close to } \\
\text { the dam } \\
(<10 \mathrm{~m})\end{array}$ & $\begin{array}{c}\text { Median } \\
\text { number of } \\
\text { detections } \\
\text { close to the } \\
\text { dam per day }\end{array}$ \\
\hline $\begin{array}{c}\text { Compensation } \\
\text { pipe }\end{array}$ & 1.10 & -2.40 & 118 & 106.33 \\
\hline Spillways & 18.53 & 16.53 & 126.5 & 11.73 \\
\hline
\end{tabular}

\section{Figure Legends}

Figure 1. Details of the study site: In the vicinity of the dam.

Figure 2. Details of the study site: Downstream view of the six spillways (left) and compensation pipe mouths during 10-years of draining (right). Spillway 1 is actively spilling water in the photograph.

Figure 3. Location of the acoustic receivers with millisecond accuracy (green points) used to obtain accurate positions, and those without millisecond accuracy (red points) used to monitor the downstream or upstream movement 
901 of eels in Bois-J oli Reservoir. Blue squares represent the location of the two 902 test transmitters and blue triangle represent the position of the 903 synchronization transmitter (ST) and reference receiver.

904 Figure 4. Cumulative quantile of error location distribution for test 905 transmitter \#1 (blue line) and test transmitter \#2 (red line). The two dashed 906 lines represent the $50 \%$ and $90 \%$ quantiles.

907 Figure 5. Example of the 10 last estimated locations ( $10 \mathrm{~min}$ ) of four silver 908 eels that swam through the first spillway. These individuals were 909 representative of all eels that swam through the spillways. The colour of the 910 dots represents the temporal evolution (yellow for the first, red for the last). 911 If less than 10 points are visible, the missing points are out of the frame.

912 Figure 6. Ten last estimated locations ( $10 \mathrm{~min}$ ) for the three eels that swam 913 through the compensation pipe. The colour of the dots represents the 914 temporal evolution (yellow for the first, red for the last). If less than 10 915 points are visible, the missing points are out of the frame.

916 Figure 7. Efficiency at passing through the dam evaluated via four metrics: 917 time to pass, time to pass after overflow, number of detections close to the 918 dam $(<10 \mathrm{~m})$, number of detections close to the dam $(<10 \mathrm{~m})$ per day, 919 according the final route. CP: compensation pipe in orange, SW: spillways in 920 green.

921 Figure 8. Detections close to the dam ( $<10 \mathrm{~m}$ ) for eels that passed through the 922 compensation pipe, viewed from above (left) and in front (right). In the 923 frontal view, the tower of the compensation pipe and spillways are depicted 924 by vertical and horizontal black dashed rectangles, respectively.

925 Figure 9. Detection of eels located close to the dam ( $<10 \mathrm{~m})$ after passing 926 through the spillways, from above (left) and in front (right), for the period 927 before (upper slide) and during (lower slide) overflow. In the frontal view, the 928 compensation pipe and spillways are depicted by the vertical and horizontal 929 black dashed rectangles, respectively. 
930 Supplementary figure 1: Schematic of the synchronization process. The

931 number of digits after a number indicates the accuracy.

\section{Annex}

956 Equation 1:

\section{Step 1: Database synchronization and removal of drift}

Before the analysis, it was necessary to synchronize the data from each receiver to the nearest millisecond, and to correct the mechanical drift in the internal clock (this phenomenon is systematically observed for each receiver). These two biases were corrected using synchronization transmitters located in the centre of the reservoir (Figure 2), at a position $5 \mathrm{~cm}$ below a receiver (hereafter, referred to as the reference receiver (RR). This transmitter was set up to emit to the nearest millisecond, every 600.000 seconds. Each synchronization acoustic signal was separately identified (\# of the sync signal; Supplementary figure 1). These two elements provided the theoretical emission time (TET, in milliseconds) (Supplementary figure 1). Given that sound velocity in water is temperature-dependent, temperature recorded by the RR for each TET was used to correct the sound velocity in real-time.

Distances between the ST and each acoustic receiver were calculated to the nearest centimetre, as shown in the distance between ST and receiver (DSR) table presented in Figure 10.

From the TET and DSR tables, the theoretical reception time (TRT) was calculated for each synchronization signal and each receiver (Supplementary figure 1). The TRT was defined as follows: 
959 where t(RR-receiver) Temp is the time taken for a signal to travel from 960 the RR to a given receiver at a particular water temperature. The time 961 taken for the signal to travel to the given receiver was calculated as 962 follows:

963

964 Equation 2:

$$
t(R R-\text { receiver })_{\text {Temp }}=\frac{d(R R-\text { receiver })}{v_{\text {Temp }}}
$$

966

967 where $d($ RR- receiver) is the distance between the RR and a given

968 receiver, and $v$ is the sound velocity in water. The velocity of the sound 969 in water was calculated as follows:

970

971 Equation 3:

972

973

$v_{\text {Temp }}=1449.2+4.6 \times$ Temp $-0.055 \times$ Temp $^{2}+0.00029 \times T e m p^{3}+(1.34-0.010 \times \mathrm{Temp}) \times(S$

974 $-35)+0.016 \times z$

975 where $\mathrm{Z}$ is the depth and Temp is the temperature. $\mathrm{Z}$ is the mean value 976 between the depth of the RR and the depth of each receiver for each 977 synchronization signal. Temp is the mean between the temperature 978 close to the RR and the temperature close to each receiver for each 979 synchronization signal. For each synchronization signal (identified based 980 on the consistency between \# of the sync. signal in the TRT Table and \# 981 of the sync. signal in the ORT Table), the difference between TRT and 982 the observed reception time (ORT) (i.e. the recording downloaded from 983 receivers) was calculated (Supplementary figure 1 ). This value was the 984 correction factor (only for sync. signals).

985 For all acoustic detection values in the ORT Table, it was necessary 986 to interpolate the correction factors. The correction for the actual 987 signals (that is not a synchronization signal) was calculated based on a 988 linear regression using the correction factors corresponding to the two 
989 closest synchronization signals. The reception time was modified 990 according to these correction factors to yield the real reception time, 991 without drift and with perfect synchronization (Supplementary figure 1). 992

\section{$993 \quad$ Step 2: Multilateration}

994 The synchronized database was used to determine accurate locations 995 using the multilateration technique, as described by Andersen (2011). 996 Multilateration is a technique that uses multiple omnidirectional sensors 997 to isolate the unknown position of a signal in two- or three-dimensional 998 Euclidian space. In the present method, this technique was only used for 999 horizontal positioning, $X$ and $Y$ (longitude and latitude). The signal from 1000 an emitter is registered by all receivers, as the signal wave expands 1001 spherically in all directions with constant propagation speed. The time 1002 difference when two receivers register the signal event is called the time 1003 difference of arrival (TDOA) (Andersen, 2011). Based on TDOA and the 1004 location of each registration (i.e. sensor positions), it is possible to 1005 deduce the location of the signal emitter through a set of hyperbolic 1006 equations described by pairwise TDOA at four hydrophones. The linear 1007 predictor function for a pairwise hydrophone $\mathrm{Hn}$ and $\mathrm{Hm}$ was defined for 1008 each i detection as follows:

1009

1010 Equation 4:

$1011 \mu$ нTDOA $(H n, H m, t(i))$

1012 $=\frac{\left(\left(x_{H n}-x(t(i))\right)^{2}+\left(y_{H n}-y(t(i))\right)^{2}\right)^{0.5}-\left(\left(x_{H m}-x(t(i))\right)^{2}+\left(y_{H m}-y(t(i))\right)^{2}\right)^{0.5}}{v}$ 1013

1014 where $x$ and $y H m / H n$ are the hydrophone positions, $x$ and $y t(i)$ are the 1015 estimated position of the transmitter at time $t$ for detection $I$, and $v$ is 1016 the sound velocity as determined from Equation 3. 
1017 To solve this equation system, we used an $\mathrm{R}$ version of the Matlab 1018 "mldivide" function.

1019

$1020 \quad$ Step 3: Filtering

1021 Having determined the locations, all estimations that were not located 1022 in the study site were removed.

1023

1024

1025 


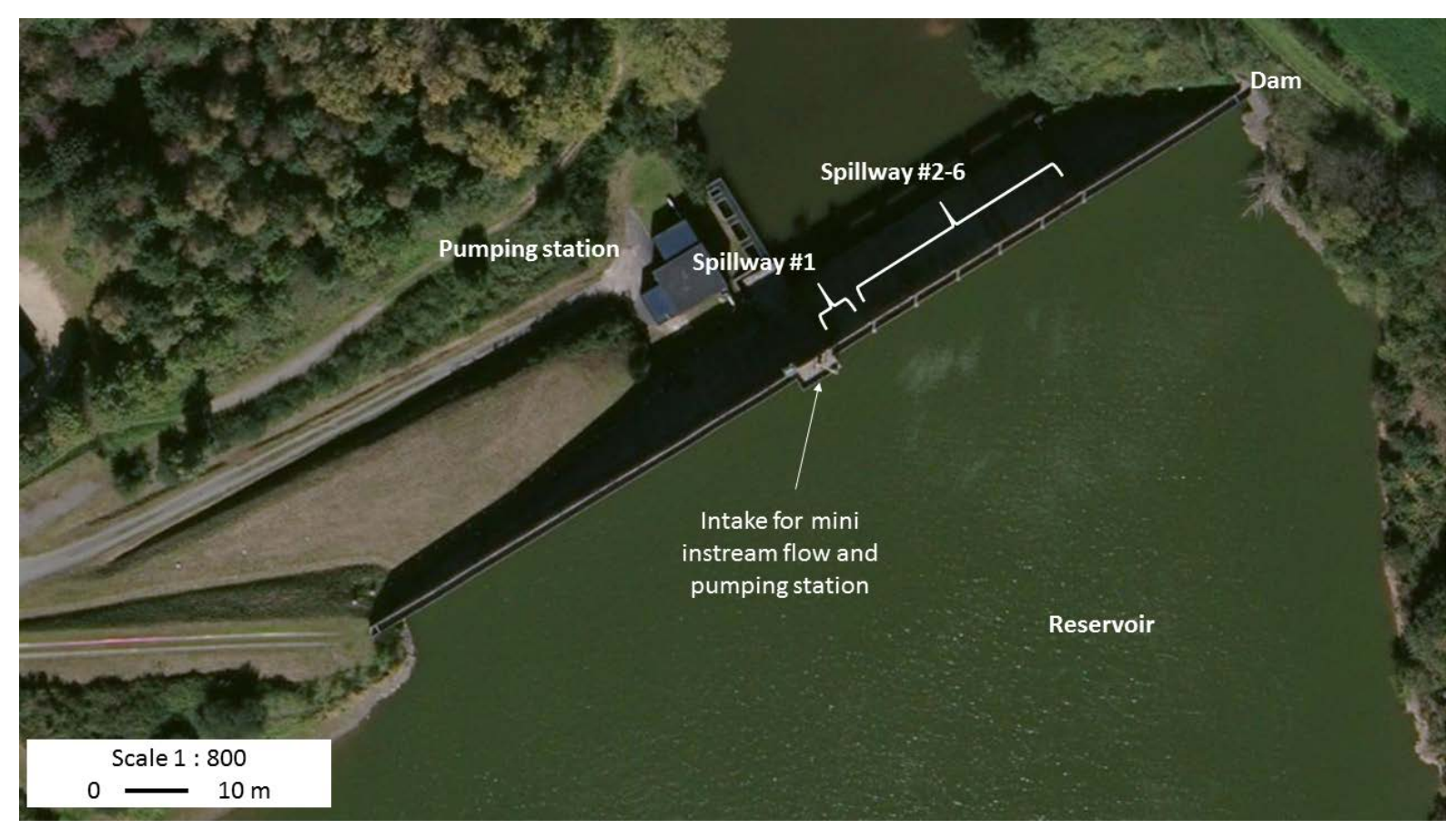

Fig. 1 

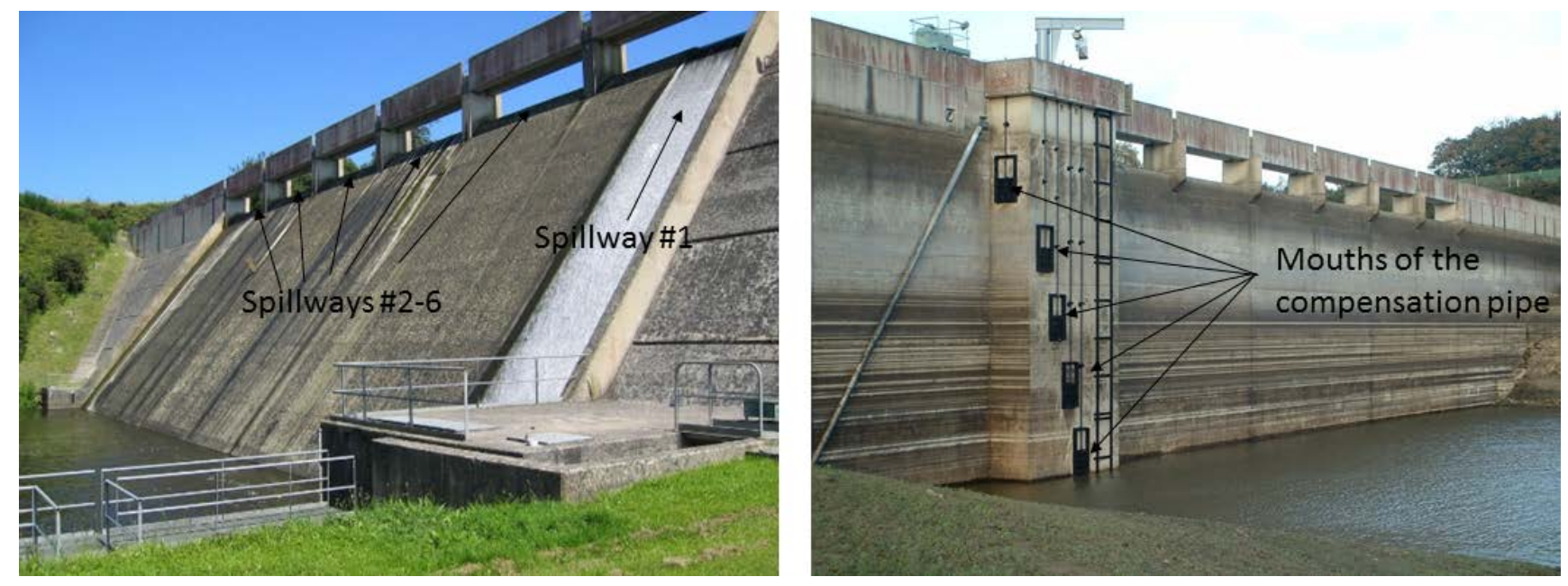

Fig. 2 


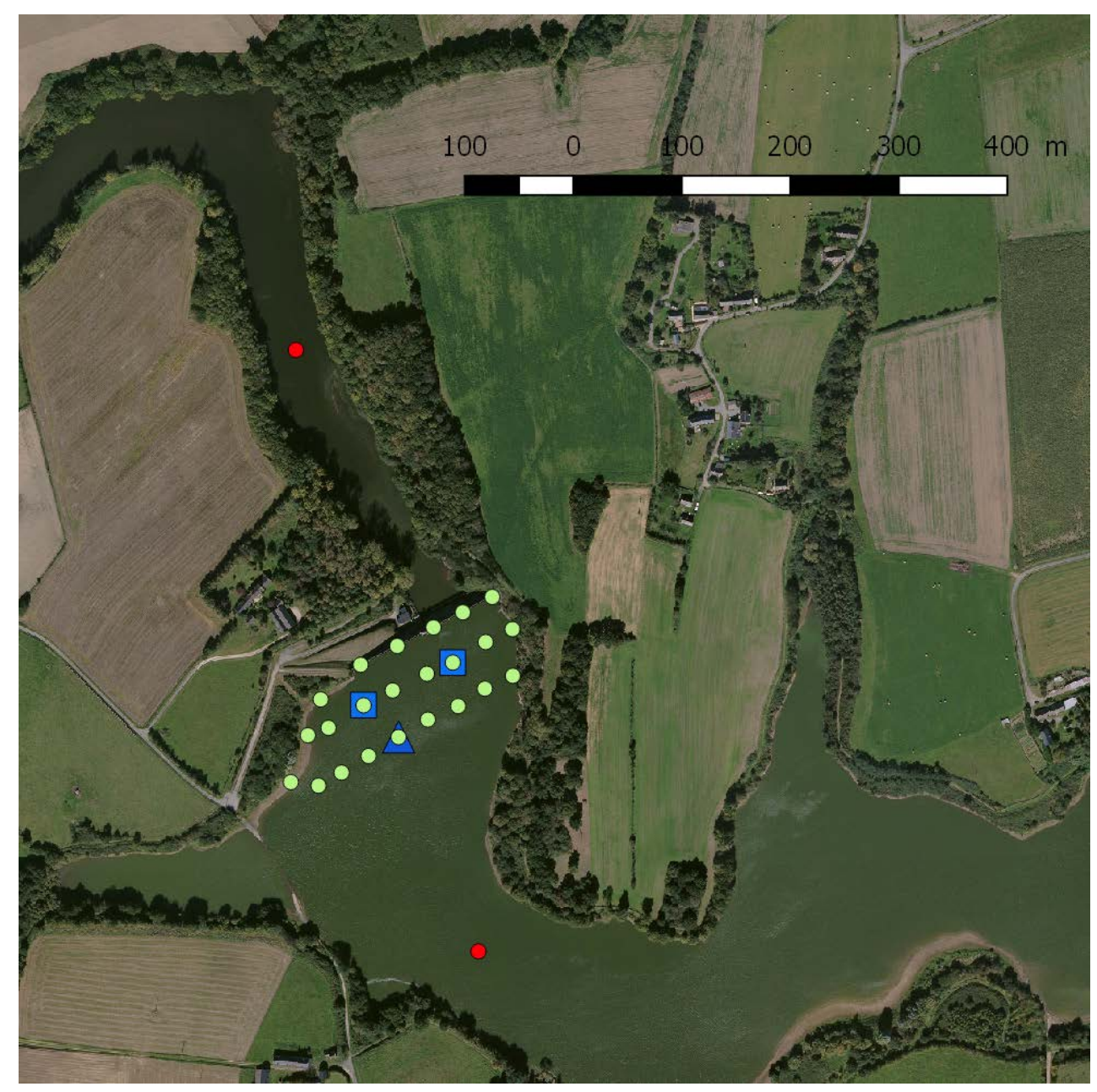

Fig. 3 


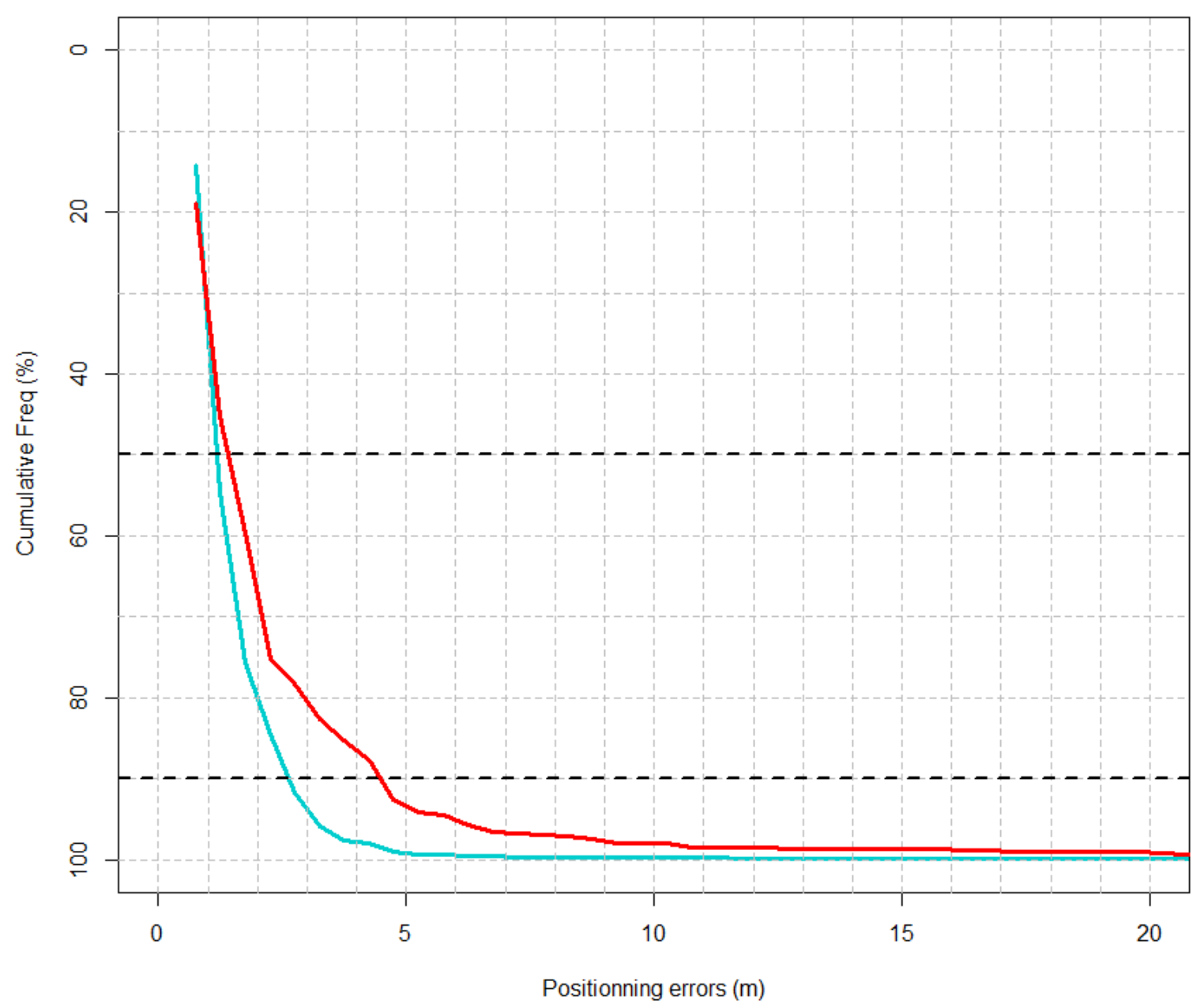

Fig. 4 


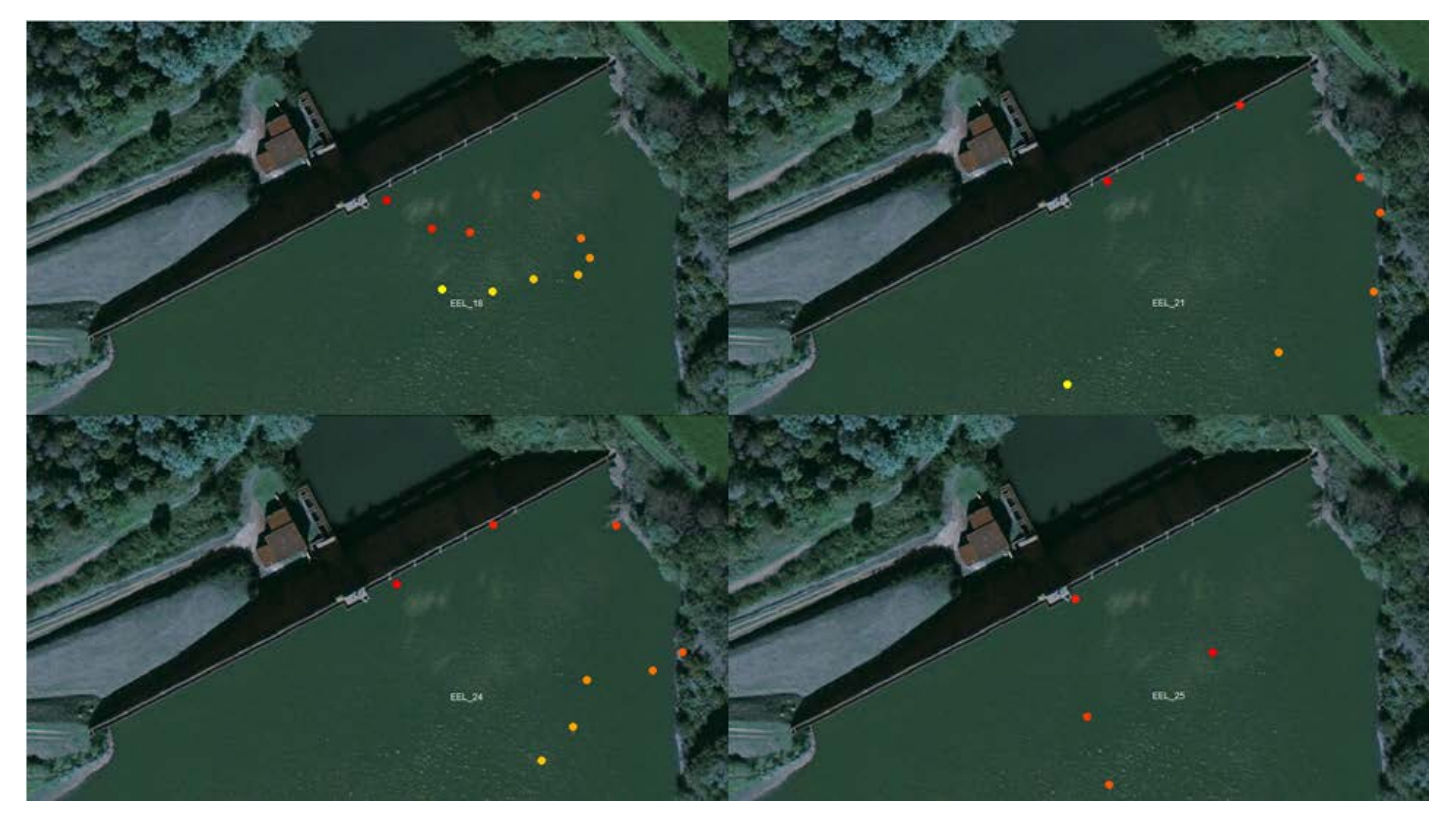

Fig. 5 


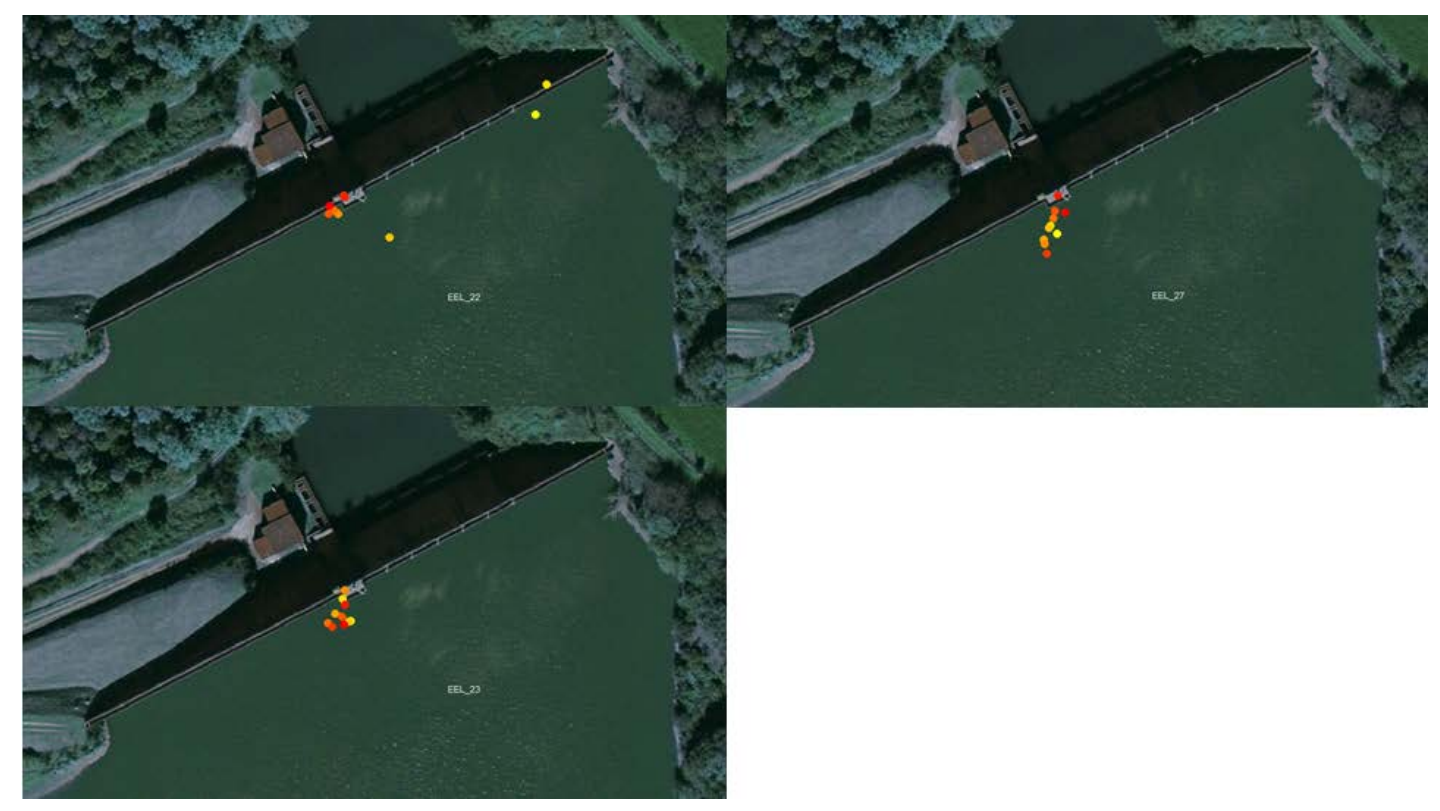

Fig. 6 

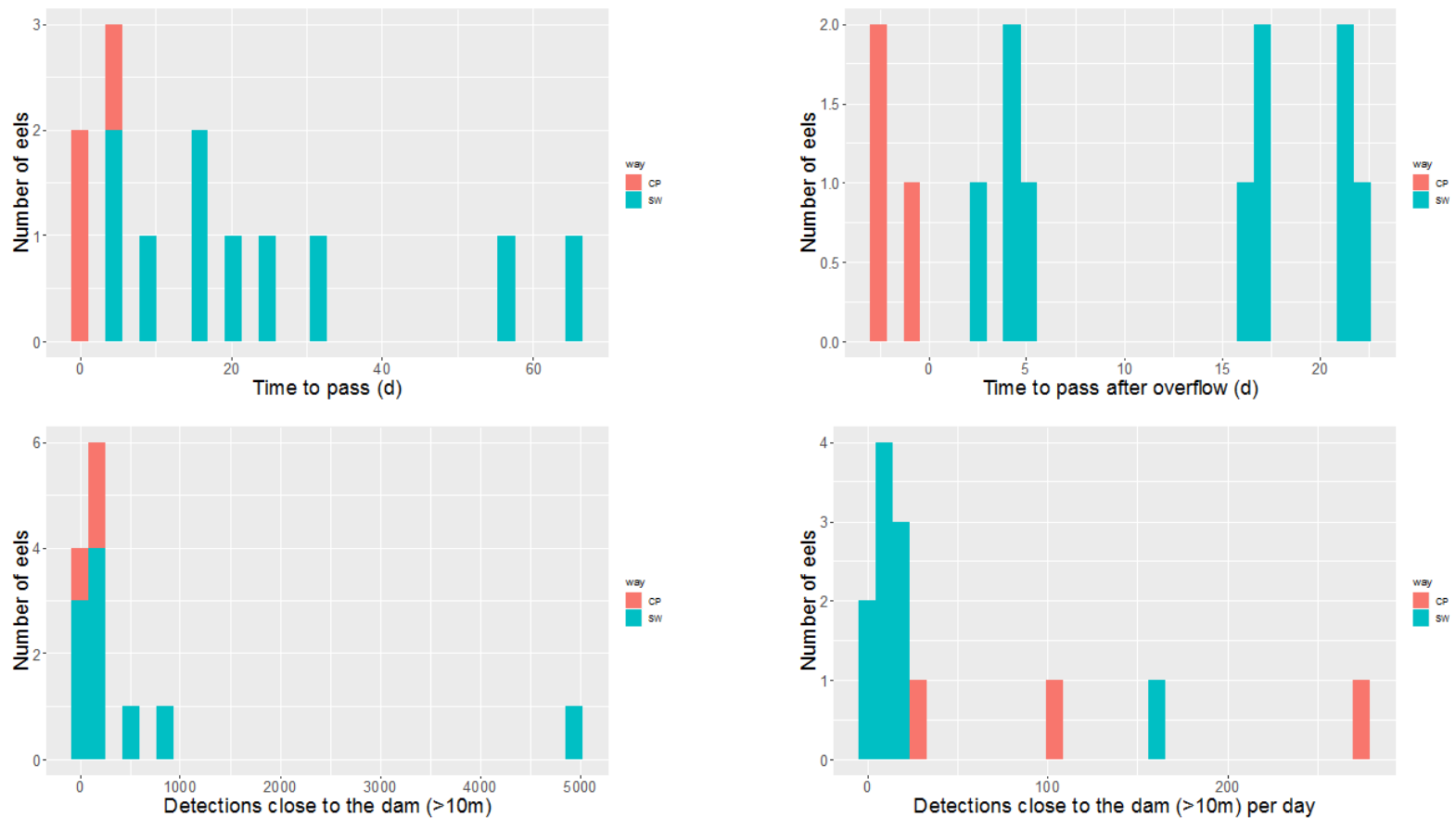

Fig. 7 


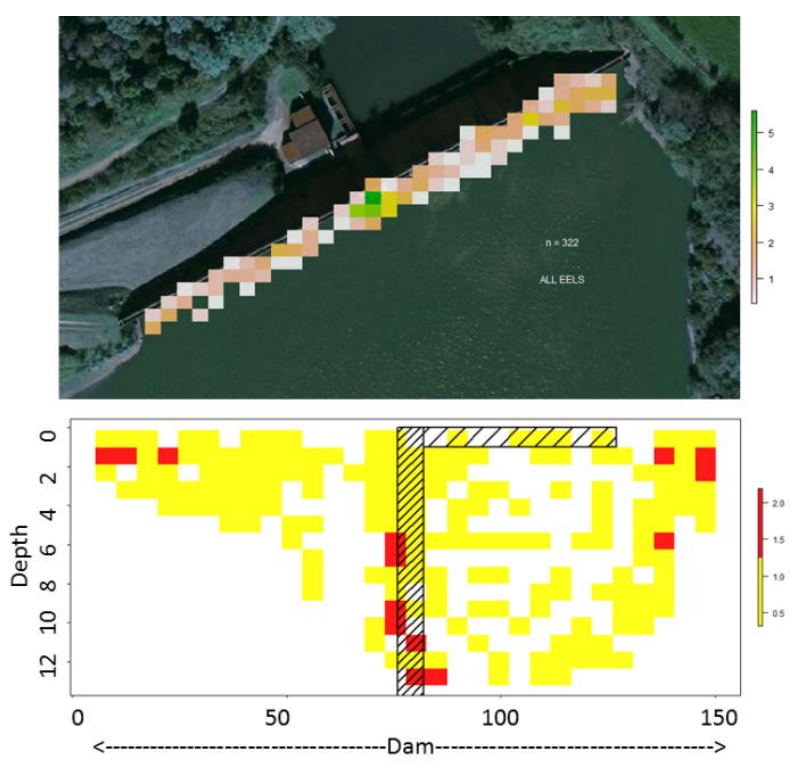

Fig. 8 

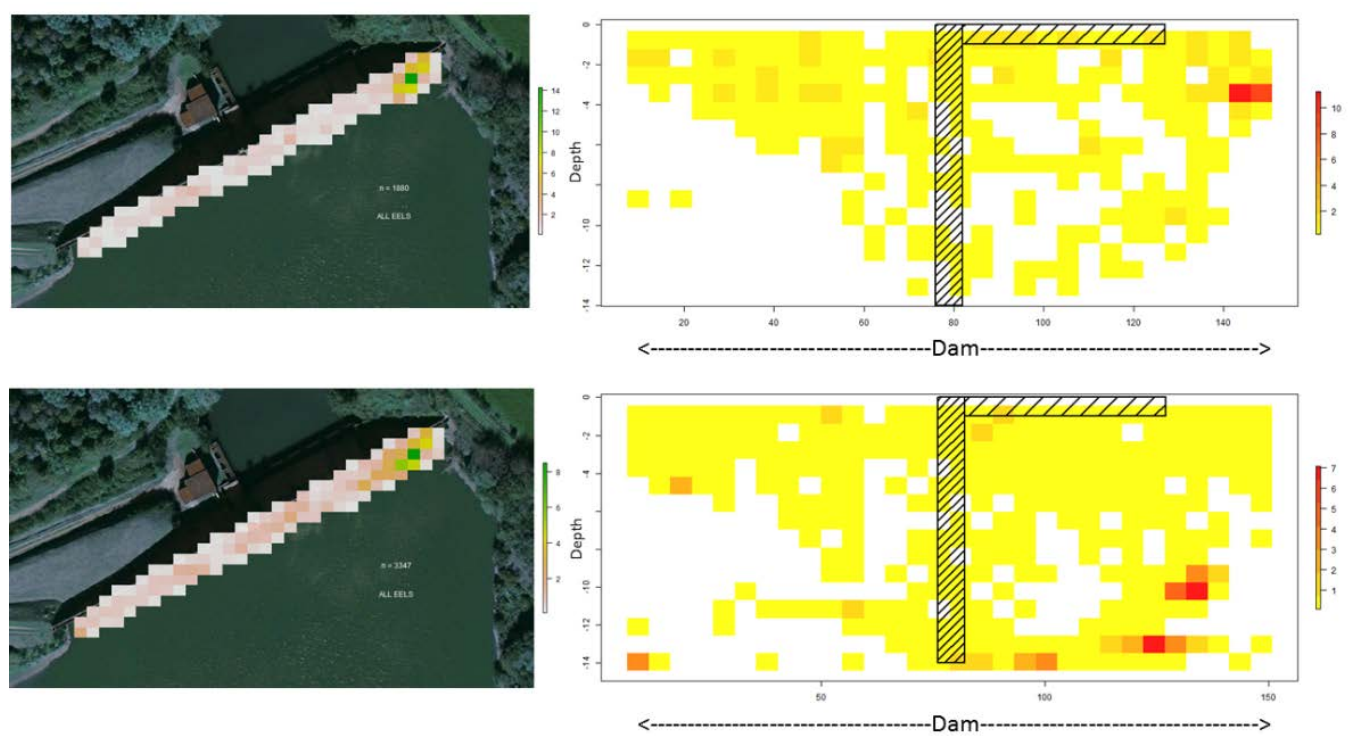

Fig. 9 